\title{
Direct, indirect and simultaneous selection as strategies for alfalfa breeding on forage yield and nutritive value ${ }^{1}$
}

\author{
Iara Gonçalves dos Santos², Cosme Damião $\mathrm{Cruz}^{2}$, \\ Moysés Nascimento ${ }^{3}$, Renato Domiciano Silva Rosado ${ }^{2}$, Reinaldo de Paula Ferreira ${ }^{4}$
}

\begin{abstract}
Alfalfa breeding aimed at trait improvement for livestock feed takes longer periods of time, if compared to many other crops. Therefore, better selection methods are necessary for the success of alfalfa breeding programs. Although knowing about selection methods is quite important, there is a notable lack of information, as regards successful solutions. This study aimed to use direct, indirect and simultaneous selection methods for selecting alfalfa cultivars, based on yield traits and nutritive value. The evaluated traits were subdivided into two groups: forage yield and nutritive value. Selection gains were estimated by direct, indirect and simultaneous selection for each group, considering the selection of the $25 \%$ best cultivars. Direct and indirect selections among genotype averages are not efficient to provide the desirable responses to the whole set of traits. The results for simultaneous selection, using the Tai index, provided a more balanced gain distribution to the set of traits in all cuts. The simultaneous selection allowed the identification of the 5681 and Verdor cultivars in the first cut, as well as ProINTA Patricia in the second cut, as superior in the two groups of evaluated traits.
\end{abstract}

KEYWORDS: Medicago sativa; selection gains; selection index.

\section{INTRODUCTION}

Alfalfa (Medicago sativa L.) is an important leguminous crop worldwide, and one of the main forage legumes in temperate countries (Ferreira et al. 2008, Annicchiarico et al. 2015). This crop has important roles in different aspects of the agricultural system, including livestock feed (Comeron et al. 2015, Li et al. 2015), crop soil conservation (Radovic \& Markovic 2009) and improvement of

\section{RESUMO}

Seleção direta, indireta e simultânea como alternativas para melhoramento de alfafa em produção e valor nutritivo da forragem

O melhoramento genético da alfafa para alimentação animal leva mais tempo do que para muitas outras culturas. Por isso, definir melhores métodos de seleção é importante para o sucesso do melhoramento da cultura. Objetivou-se utilizar métodos de seleção direta, indireta e simultânea, para a seleção de cultivares de alfafa, com base em características de produção e valor nutritivo. As características avaliadas foram subdivididas em dois grupos: produção e valor nutritivo. Os ganhos de seleção foram estimados por seleção direta, indireta e simultânea para cada grupo, considerando-se a seleção das $25 \%$ melhores cultivares. As seleções direta e indireta entre as médias dos genótipos não são eficientes para fornecer as respostas desejáveis para todo o conjunto de características. Os resultados da seleção simultânea, utilizandose o índice de Tai, forneceram uma distribuição de ganhos mais equilibrada para os conjuntos de características em todos os cortes. A seleção simultânea permitiu a identificação das cultivares 5681 e Verdor no primeiro corte, bem como a ProINTA Patricia no segundo corte, como superiores, nos dois grupos de características avaliadas.

PALAVRAS-CHAVE: Medicago sativa; ganhos de seleção; índice de seleção.

soil nitrogen supply (Bouton 2007). However, even though it presents a potential in different soil and climatic conditions (Viana et al. 2004), $90 \%$ of the alfalfa production has been concentrated in the Brazilian states of Paraná and Rio Grande do Sul (Ferreira \& Vilela 2015).

The main targets of alfalfa breeding are the productive potential and nutritional value (Tucak et al. 2014), which are determined by a number of traits, such as crude protein and dry matter yield

1. Manuscript received in Mar./2018 and accepted for publication in Jun./2018 (http://dx.doi.org/10.1590/1983-40632018v4851950).

2. Universidade Federal de Viçosa, Departamento de Biologia Geral, Viçosa, MG, Brasil. E-mails: iaraminas@hotmail.com, cdcruz@ufv.br, rosado.rds@gmail.com.

3. Universidade Federal de Viçosa, Departamento de Estatística, Viçosa, MG, Brasil. E-mail: moysesnascim@ufv.br. 4. Empresa Brasileira de Pesquisa Agropecuária (Embrapa Pecuária Sudeste), São Carlos, SP, Brasil.

E-mail: reinaldo.ferreira@embrapa.br. 
(Julier et al. 2000, Botrel et al. 2001, Guines et al. 2002, Katepamupondwa et al. 2002, Souza Sobrinho et al. 2004). Selection strategies for more than one trait in alfalfa have been mainly tandem selection, independent culling levels and index selection, where the selection units are evaluated together, in relation to a set of traits of interest (Basigalup \& Odorizzi 2011).

Independent culling levels and tandem selection are carried out by means of univariate strategies, and can be used with restrictions, since they involve direct and indirect selection. Direct selection may provide superior individual gains in the trait under selection. However, if the trait suffers a great environmental influence, the selection precision will be low (Hallauer et al. 2010). Indirect or correlated response is used mainly for the selection of traits that have low heritability or are difficult to measure (Cruz et al. 2014). In such cases, the indirect selection based on secondary traits of low environmental influence, of easy measurement and genetically correlated with the target trait, is a rather interesting alternative to maximize predictive accuracy.

Since most alfalfa traits exhibit a complex genetic control (Milic et al. 2014, Li et al. 2015), simultaneous selection has been used, since it maximizes the chances of success in the breeding process by providing balanced gains to all traits, making it possible to obtain gains even for unfavorably correlated traits (Cruz et al. 2014). Vasconcelos et al. (2010) found higher gains for alfalfa traits selection, when applying direct selection. However, this selection led to an increase in the susceptibility of the cultivars, in relation to diseases incidence. Moreover, none of the direct selection methods provided satisfactory gains for all traits jointly.

Information about the best selection strategies allow maximizing gains and guiding the choice of superior alfalfa cultivars. Although knowing about selection methods is quite important, there is a notable lack of information regarding successful solutions. Thus, this study aimed to test direct, indirect and simultaneous selection methods for alfalfa breeding, based on traits of forage yield and nutritive value, in order to select cultivars that combine high yield and nutritive value.

\section{MATERIAL AND METHODS}

Data from 77 cultivars evaluated in four alfalfa cuts were used (Table 1). The data came from an experiment carried out at the Embrapa Pecuária Sudeste, located in the city of São Carlos, São Paulo state, Brazil. The cuts were performed in November 2015 and February, May and August 2016.

Table 1. Alfalfa cultivars evaluated in the experiment.

\begin{tabular}{clclclcl}
\hline Accession & \multicolumn{1}{c}{ Cultivar } & Accession & Cultivar & Accession & Cultivar & Accession & Cultivar \\
\hline 1 & 5681 & 21 & DK 192 & 40 & Mecha & 59 & Rio Grande \\
2 & Aca 900 & 22 & DK 194 & 41 & Medina & 60 & Ruano 1 \\
3 & Aca 901 & 23 & Don Enrique & 42 & Milonga II & 61 & Ruano 2 \\
4 & Activa & 24 & F 708 & 43 & Monarca & 62 & Sequel \\
5 & Bacana 1 & 25 & Flórida 77 & 44 & Monarca SP INTA & 63 & Sequel 2 \\
6 & Bacana 2 & 26 & G 909 & 45 & P 30 & 64 & Siriver 2 \\
7 & Bar Pal 5 & 27 & Gapp 969 & 46 & P 5715 & 65 & SPS 6550 \\
8 & Bar Pal 10 & 28 & Gateado & 47 & Patriarca & 66 & Trinidad 87 \\
9 & Baralfa 85 & 29 & Kern & 48 & Patricia & 67 & Verdor \\
10 & Bárbara SP INTA & 30 & Le N 1 & 49 & Pintado & 68 & Verzi \\
11 & California 50 & 31 & LE N 2 & 50 & Pinto & 69 & Victoria SP INTA \\
12 & Cuf 101 & 32 & LE N 3 & 51 & Primavera & 70 & Villa \\
13 & CW 1010 & 33 & LE N 4 & 52 & ProINTA Carmina & 71 & Winter \\
14 & CW 194 & 34 & LPS 8500 & 53 & ProINTA Luján & 72 & WL 1058 \\
15 & CW 620 & 35 & Magna 601 & 54 & ProINTA Mora & 73 & WL 516 \\
16 & CW 830 & 36 & Magna 804 & 55 & ProINTA Patricia 1 & 74 & WL 525 \\
17 & Diamond & 37 & Magna 860 & 56 & ProINTA Patricia 2 & 75 & WL 818 \\
18 & DK 166 & 38 & Magna 868 & 57 & ProINTA Super Monarca & 76 & WL 903 \\
19 & DK 181 & 39 & Maitena & 58 & Queen 910 & 77 & Crioula \\
20 & DK 187 R & & - & & & - & -
\end{tabular}


A randomized block design, with three replications, was used, according to the following model: $\mathrm{Y}_{\mathrm{ij}}=$ $\mu+\mathrm{G}_{\mathrm{i}}+\mathrm{B}_{\mathrm{j}}+\mathrm{e}_{\mathrm{ij}}$, where $Y_{i j}$ is the genotype value of the $j$-th block, evaluated in the $i$-th genotype; $\mu$ the overall average of the trials; $G_{i}$ the effect of the $i$-th genotype; and $e_{i j}$ the experimental error associated with the observation $Y_{i j}$, with $e_{i j} \sim N\left(0 ; \sigma^{2}\right)$.

Each experimental unit consisted of four rows of $4.0 \mathrm{~m}$ in length, spaced at $20 \mathrm{~cm}$. Cultivars were irrigated by a center pivot (Rassini 2002) for the first three cuts. Subsequently, irrigation was suspended, and the fourth cut data were collected under water deficit. All other traits were evaluated according to the recommendations for the crop (Ferreira et al. 2008).

The traits were divided into two groups: forage yield and nutritive value. Yield traits included plant height, measured from the ground to the top of the inflorescence; dry matter yield $\left(\mathrm{kg} \mathrm{ha}^{-1}\right)$, obtained by manually cutting the plants at $8-10 \mathrm{~cm}$ above the ground, when each cultivar reached $10 \%$ of flowering, or when the basal shoots reached an average height of 3-5 cm; and susceptibility to diseases, determined according to the percentage of leaf area attacked in each plot (Vasconcelos et al. 2010). The nutritive value traits included crude protein, in vitro dry matter digestibility, neutral detergent fiber, acid detergent fiber, lignin and stem/leaf ratio.

Direct and indirect selection gains were estimated for each group in each cut, considering the selection of the $25 \%$ best cultivars. For the forage yield group, the selection according to plant height, dry matter yield and susceptibility to diseases was performed aiming to increase the trait values. Considering the nutritive value group of traits, an increase was established for crude protein and in vitro dry matter digestibility, and a decrease for the other traits.

The estimates of direct gain were obtained according to the expression: $\Delta \mathrm{G} \%=\left[100\left(\mathrm{SD} \mathrm{x} \mathrm{h}^{2}\right)\right] / \overline{\mathrm{x}}$, where $\Delta G \%$ is the selection gain expressed in percentage; $S D$ the selection differential; $h^{2}$ the heritability coefficient; and $\bar{x}$ the original average of the trait $X$.

Indirect gains were estimated by: $\Delta \mathrm{G}_{\mathrm{x}(\mathrm{y})} \%=$ $\left(\mathrm{SD}_{\mathrm{x}(\mathrm{y})} \mathrm{x} \mathrm{h}_{\mathrm{x}}^{2}\right) / \overline{\mathrm{x}}$, where $\Delta G_{x(y)} \%$ is the indirect selection gain of the trait $X$ selected in $Y ; S D$ the indirect selection differential of the trait $X$ selected in $Y ; h^{2}$ the heritability coefficient of the trait $X$; and $\bar{x}$ the original average of the trait $X$.
The selection index proposed by Tai (1977) was used for simultaneous selection. This index allows secondary traits for which no maximum gain is desired to be included in the index, to aid in the gain of the main traits. To construct this index, it should be considered that the economic values of the secondary traits are null in the genotypic aggregate (Cruz et al. 2014).

Among the nutritive value traits, crude protein and in vitro dry matter digestibility were considered as the main traits, and the others as secondary. Thus, the genotypic aggregate $(\mathrm{H})$ and the index $(\mathrm{I})$ were given by: $\mathrm{H}=\mathrm{a}_{1} \mathrm{~g}_{1}+\mathrm{a}_{2} \mathrm{~g}_{2}(1)$ and $\mathrm{I}=\mathrm{b}_{1} \mathrm{x}_{1}+\mathrm{b}_{2} \mathrm{x}_{2}+\mathrm{b}_{3} \mathrm{x}_{3}+$ $\mathrm{b}_{4} \mathrm{x}_{4}(2)$, where $a$ stands for the economic weights; $g$ for genotypic values; $x$ for phenotypic values; and $b$ for the trait coefficients in the index. The vector of desired gains was established based on a genetic standard deviation for each trait (Cruz et al. 2014).

Vector $b$ was estimated from the following equations: $\mathrm{P} \hat{\mathrm{b}}=\mathrm{Ga}(3)$ and $\mathrm{G} \hat{b}=\Delta \mathrm{g}_{\mathrm{d}}$ (4), where $G$ is the matrix of genotypic covariance between variables; $P$ the matrix of phenotypic covariance between variables; and $\Delta g_{d}$ the vector of desired gains, replacing the equation 4 in $3: \mathrm{a}=\mathrm{GP}^{-1} \mathrm{G} \Delta \mathrm{g}_{\mathrm{d}}$, considering:

$$
\mathrm{a}=\left[\begin{array}{l}
\mathrm{C}_{1} \\
\mathrm{C}_{2}
\end{array}\right] \text { and } \Delta \mathrm{g}_{\mathrm{d}}=\left[\begin{array}{l}
\mathrm{d}_{1} \\
\mathrm{~d}_{2}
\end{array}\right]
$$

where $c_{1}, c_{2}, d_{1}$ and $d_{2}$ are vectors of dimension $2 \times 1$. And also considering:

$$
c_{2}=\Phi \text { and } \omega=\left[\begin{array}{ll}
\omega_{11} & \omega_{12} \\
\omega_{21} & \omega_{22}
\end{array}\right]
$$

where $\omega_{11}, \omega_{12}, \omega_{21}$ and $\omega_{22}$ are $2 \times 2$ matrices. Therefore:

$$
\begin{aligned}
& a=\left[\begin{array}{l}
C_{1} \\
C_{2}
\end{array}\right]=\left[\begin{array}{ll}
\omega_{11} & \omega_{12} \\
\omega_{21} & \omega_{22}
\end{array}\right]=\left[\begin{array}{c}
d_{1} \\
d_{2}
\end{array}\right]=\left[\begin{array}{lll}
\omega_{11} d_{1} & \omega_{12} d_{2} \\
\omega_{21} d_{1} & \omega_{22} d_{2}
\end{array}\right] \text { and } \\
& \Delta g_{d}=\left[\begin{array}{l}
d_{1} \\
d_{2}
\end{array}\right]=\Delta g_{d}=\left[\begin{array}{c}
d_{1} \\
-\omega_{22}^{-1} \omega_{21} d_{1}
\end{array}\right]
\end{aligned}
$$

Thus, vector $b$ was estimated by the equation 3 or 4 . Similar reasoning can be done for the forage yield group, in which the dry matter yield was considered as the main trait, and the others as secondary. This study did not evaluate realized gains. 
Heritabilities were expressed by: $\mathrm{h}^{2}=\left(\sigma_{\mathrm{g}}{ }^{2}\right) /$ $\left(\sigma_{\mathrm{f}}^{2}\right)$, where $h^{2}$ is the broad-sense heritability coefficient; $\sigma_{g}^{2}$ the genotypic variance; and $\sigma_{f}^{2}$ the phenotypic variance.

Correlation coefficients were expressed by the phenotypic $\left[\mathrm{r}_{\mathrm{f}}=\mathrm{PMG}_{\mathrm{xy}} / \sqrt{ }\left(\mathrm{QMG}_{\mathrm{x}} \mathrm{QMG}_{\mathrm{y}}\right)\right]$ and genotypic $\left\{\mathrm{r}_{\mathrm{g}}=\left[\left(\mathrm{PMG}_{\mathrm{xy}}-\mathrm{PMR}_{\mathrm{xy}}\right) / \mathrm{r}\right] / \sqrt{\sigma}{ }^{2}{ }_{\mathrm{gx}} \hat{\sigma}^{2}{ }_{\mathrm{gy}}\right\}$ correlations, where $P M G_{x y}$ is the mean product between the genotypes for traits; $P M R_{x y}$ the mean product between residuals for the traits $x$ and $y$; $Q M G_{y}$ the mean square between genotypes for the trait $y ; Q M G_{x}$ the mean square between genotypes for the trait $x ; \hat{\sigma}^{2}{ }_{g x}$ and $\hat{\sigma}_{g y}^{2}$ the estimators of genotypic variance for the traits $x$ and $y$, respectively.

All estimates of selection gains were performed using the Genes software (Cruz 2013).

\section{RESULTS AND DISCUSSION}

For the forage yield and nutritive value traits, the coefficients of variation were compatible with those obtained by Vasconcelos et al. (2010) (Tables 2 and 3). Considering the forage yield group, it was possible to observe that, in the first cut, the cultivars presented the highest averages for dry matter yield, plant height and stem/leaf ratio, when compared to other cuts. However, the coefficient of experimental variation (CVe)/coefficient of genetic variation $(\mathrm{CVg})$ ratio was low, indicating an unfavorable scenario for selection and genetic gains. According to Cruz et al. (2014), CVg/CVe ratio values close to the unit represent a favorable scenario for selection. As for susceptibility to diseases, there was no variability. However, the averages for this trait classify them as moderately resistant. For dry matter yield, the genotypic variability was low, revealing an unfavorable scenario for selection. The heritability for this trait was low, when compared to the values obtained for the other cuts, indicating the occurrence of high environmental variance.

Heritability for plant height was high (77\%, $82 \%$ and $74.49 \%$, respectively), indicating a high reliability of the phenotypic value, as an indicator of the genotypic value (Falconer 1981, Robins et al. 2007). For dry matter yield and susceptibility to diseases, the estimates for coefficient of genetic variation assumed higher values in the second cut than those obtained in the first cut. It is assumed that low CVg estimates, as found in the first cut, are the result of low genotypic variance (Silva et al. 2012). In the fourth cut (Table 2), in which the data were obtained under water deficit conditions, the susceptibility to diseases showed low CVg and heritability, indicating low genotypic variability.

Table 2. Estimates of genetic and environmental parameters associated with alfalfa cultivars evaluated for forage yield traits in four cuts.

\begin{tabular}{|c|c|c|c|c|}
\hline Cuts & Parameters* & Dry matter yield & Plant height & Susceptibility to diseases \\
\hline \multirow{5}{*}{$\mathrm{C} 1$} & Overall average & $2,287.25$ & 51.50 & 2.40 \\
\hline & $\mathrm{CVe}(\%)$ & 24.43 & 6.17 & 23.57 \\
\hline & $\operatorname{CVg}(\%)$ & 6.44 & 4.73 & 0.00 \\
\hline & $\mathrm{CVg} / \mathrm{Cve}$ & 0.26 & 0.77 & 0.00 \\
\hline & $\mathrm{h}^{2}$ & 17.27 & 63.77 & 0.00 \\
\hline \multirow{5}{*}{$\mathrm{C} 2$} & Overall average & $1,631.66$ & 43.91 & 2.75 \\
\hline & $\mathrm{CVe}(\%)$ & 21.16 & 6.70 & 12.13 \\
\hline & $\operatorname{CVg}(\%)$ & 12.59 & 7.25 & 9.78 \\
\hline & $\mathrm{CVg} / \mathrm{Cve}$ & 0.59 & 1.08 & 0.81 \\
\hline & $\mathrm{h}^{2}$ & 51.52 & 77.82 & 66.10 \\
\hline \multirow{5}{*}{ C3 } & Overall average & $1,841.34$ & 50.57 & 1.73 \\
\hline & $\mathrm{CVe}(\%)$ & 18.57 & 9.47 & 31.69 \\
\hline & $\operatorname{CVg}(\%)$ & 11.47 & 9.34 & 12.77 \\
\hline & $\mathrm{CVg} / \mathrm{Cve}$ & 0.61 & 0.99 & 0.40 \\
\hline & $\mathrm{h}^{2}$ & 53.34 & 74.49 & 32.75 \\
\hline \multirow{5}{*}{$\mathrm{C} 4$} & Overall average & $1,362.77$ & 36.81 & 2.91 \\
\hline & $\mathrm{CVe}(\%)$ & 18.96 & 16.24 & 9.89 \\
\hline & $\operatorname{CVg}(\%)$ & 29.04 & 26.24 & 0.82 \\
\hline & $\mathrm{CVg} / \mathrm{Cve}$ & 1.53 & 1.62 & 0.08 \\
\hline & $\mathrm{h}^{2}$ & 87.55 & 88.68 & 2.02 \\
\hline
\end{tabular}

* CVe (\%): coefficient of experimental variation; $\mathrm{CVg}(\%)$ : coefficient of genetic variation. 
For dry matter yield and plant height, the CVg and heritability values were high, indicating that the differences are predominantly determined by genetic causes. However, the experimental conditions, with drought, impacted on the cultivars performance, providing a considerable reduction in their averages.

As the alfalfa of the fourth cut was kept under water deficit, the genetic parameters allowed to select cultivars more tolerant to drought, an interesting trait for breeding programs. Drought tolerant cultivars may be directed to the increase of alfalfa yield in arid and semi-arid regions. These cultivars can facilitate the reproduction to improve resistance to drought and water use efficiency in alfalfa. As the world population is expected to reach 11.2 billion by 2100 (United Nations 2017), agriculture is challenged to produce more with less water inputs. This will require a substantially more efficient crop production from a smaller irrigation water resource. As a consequence, obtaining drought-resistant alfalfa cultivars and water efficiency is a key to sustainable agriculture. The warmer and drier climate predicted by global climate change also makes imperative that climate-resistant crops be developed (Zhang et al. 2015).

In indirect selection, breeders look for auxiliary traits of high heritability and little environment influence. Accordingly, plant height, whose heritability has always been higher than dry matter yield, is a good trait for indirect selection (Table 2). Susceptibility to diseases had an unpredictable behavior, considering the low genetic variance and heritability observed in our experiment. Its effects depend on several other factors, such as occurrence of pathogens, host populations and combinations of favorable environmental factors.

Similarly, for the nutritive value traits in the first cut, the $\mathrm{CVg} / \mathrm{CVe}$ ratio was low (Table 3 ). In that environment, the selection for both forage yield and nutritive value traits would be impaired. For in vitro dry matter digestibility, the variance estimate was low, and that result was also observed in the other cuts throughout the year. A similar result was reported by Rassini et al. (2007), who also pointed out that values between $65 \%$ and $70 \%$ for this trait indicate a high digestibility and, thus, the low variability of the cultivars for this particular trait assumes a great importance. Lignin, neutral detergent fiber and acid detergent fiber presented values of $8.51 \%$, $44.37 \%$ and $30.99 \%$, respectively, compatible with the optimal values for alfalfa (Rassini et al. 2007).

The crude protein average in all cuts varied between $25.70 \%$ and $26.48 \%$ (Table 3). These

Table 3. Estimates of genetic and environmental parameters associated with alfalfa cultivars evaluated for the traits in the nutritive value group.

\begin{tabular}{|c|c|c|c|c|c|c|c|}
\hline Cuts & Parameters & $\mathrm{L}^{*}$ & $\mathrm{CP}$ & IVDMD & NDF & $\mathrm{ADF}$ & SLR \\
\hline \multirow{5}{*}{$\mathrm{C} 1$} & Overall average & 8.51 & 25.70 & 69.27 & 44.37 & 30.99 & 0.83 \\
\hline & $\mathrm{CVe}(\%)$ & 17.43 & 5.46 & 3.74 & 11.95 & 10.21 & 10.99 \\
\hline & $\operatorname{CVg}(\%)$ & 10.05 & 2.94 & 1.15 & 5.90 & 4.94 & 4.34 \\
\hline & $\mathrm{CVg} / \mathrm{Cve}$ & 0.58 & 0.54 & 0.31 & 0.49 & 0.48 & 0.40 \\
\hline & $h^{2}$ & 49.93 & 46.45 & 22.02 & 42.26 & 41.28 & 31.89 \\
\hline \multirow{5}{*}{$\mathrm{C} 2$} & Overall average & 7.83 & 26.76 & 69.28 & 47.04 & 29.62 & 0.67 \\
\hline & $\mathrm{CVe}(\%)$ & 5.38 & 3.82 & 1.75 & 4.31 & 4.18 & 13.35 \\
\hline & CVg $(\%)$ & 0.00 & 2.87 & 0.37 & 0.00 & 1.67 & 9.70 \\
\hline & $\mathrm{CVg} / \mathrm{Cve}$ & 0.00 & 2.87 & 0.37 & 0.00 & 1.67 & 0.72 \\
\hline & $\mathrm{h}^{2}$ & 0.00 & 62.97 & 11.85 & 0.00 & 32.36 & 61.26 \\
\hline \multirow{5}{*}{$\mathrm{C} 3$} & Overall average & 7.18 & 26.99 & 69.17 & 42.85 & 31.51 & 0.73 \\
\hline & $\mathrm{CVe}(\%)$ & 5.84 & 5.85 & 1.89 & 3.84 & 4.01 & 13.81 \\
\hline & CVg $(\%)$ & 1.42 & 5.82 & 0.65 & 1.82 & 2.31 & 9.15 \\
\hline & $\mathrm{CVg} / \mathrm{Cve}$ & 0.24 & 0.99 & 0.34 & 0.47 & 0.58 & 0.66 \\
\hline & $\mathrm{h}^{2}$ & 15.05 & 74.79 & 26.17 & 40.44 & 49.84 & 56.83 \\
\hline \multirow{5}{*}{$\mathrm{C} 4$} & Overall average & 7.18 & 26.48 & 71.18 & 39.49 & 30.57 & 0.52 \\
\hline & $\mathrm{CVe}(\%)$ & 8.24 & 3.54 & 1.57 & 6.96 & 4.78 & 18.53 \\
\hline & CVg $(\%)$ & 3.30 & 3.61 & 0.70 & 2.25 & 0.00 & 14.22 \\
\hline & $\mathrm{CVg} / \mathrm{Cve}$ & 0.40 & 1.02 & 0.44 & 0.32 & 0.00 & 0.77 \\
\hline & $\mathrm{h}^{2}$ & 32.50 & 75.66 & 37.17 & 23.82 & 0.00 & 63.88 \\
\hline
\end{tabular}

* L: lignin; CP: crude protein; IVDMD: in vitro dry matter digestibility; NDF: neutral detergent fiber; ADF: acid detergent fiber; SLR: stem/leaf ratio; CVe (\%): coefficient of experimental variation; $\mathrm{CVg}(\%)$ : coefficient of genetic variation. 
values were higher than those found by Costa et al. (2006) and Vasconcelos et al. (2010), and represent optimum values. Except for the first cut, heritability estimates for this trait were high, indicating a high relation between phenotypic and genotypic values. In the second cut, lignin and neutral detergent fiber presented a null genetic variance and, therefore, it was not possible to obtain estimates for $\mathrm{CVg}$ and heritability. In the fourth cut, the same was observed for acid detergent fiber (Table 3). It is worth noting that crude protein and in vitro dry matter digestibility values $(26.48 \%$ and $71.18 \%)$ remained high, even in an unfavorable environment. This fact may be explained by the higher yields observed in irrigated cuts, which lead to the crude protein dilution in the forage. Although Botrel et al. (2001) reported that, in the dry season, the nutritive values fall sharply, the values for the fourth cut remained at the same level as the others.

For the purpose of predicting gains by simultaneous or indirect selection, the knowledge of the relationship among traits is indispensable. At first, the magnitude, sign and nature of the correlations are calculated to verify whether they are genetically determined or resulting from environmental causes (Cruz et al. 2014). This analysis is fundamental for understanding selection gains in breeding programs. For the forage yield traits, the genotype correlation estimates did not always exceed phenotype, indicating that the genetic factors do not influence as much as environmental factors in the determination of correlations (Table 4). In the first cut, susceptibility to diseases showed zero correlation with the other traits, because it did not present genotypic variance.

Estimates of genotypic and phenotypic correlations among the nutritive value traits are presented in Table 5. For the first cut, neutral detergent fiber and in vitro dry matter digestibility showed null correlations with the other traits, because they did not present genotypic variance. The same was observed in the fourth cut for acid detergent fiber. The negative correlations between crude protein and neutral detergent fiber, and between crude protein and acid detergent fiber, found in all cuts suggest a linear decreasing association between these traits. In general, estimates of genotypic correlations were superior to the phenotypic correlations, indicating that environmental factors influence correlation estimates.

Considering the forage yield traits, direct selections provided great individual gains (Table 6).
Dry matter yield, for example, reached a gain level of $27.11 \%$ in the last cut. In the first cut, susceptibility to diseases showed a null genetic variance, and dry matter yield was not significant, but because they do not interfere in the gains of the others, these traits were maintained in the analysis. For the other cuts, the correlation between dry matter yield and plant height stands out, showing that, for traits submitted to indirect selection, the relationships between them exert an influence on response.

According to Cruz et al. (2014), direct selection may provide satisfactory gains in the traits under selection. However, for traits that suffer a great environmental influence, the selection precision will be low, due to the existence of genetic correlations that lead to a change in the behavior of several other traits. In the second cut, for example, the direct selection for dry matter yield, which presented a heritability of $51.52 \%$, provided positive gains in all other traits. According to Falconer (1981), correlated responses may provide greater gains than those of direct responses. However, the expression used in the present study for indirect responses makes possible that, at most, the correlated response is equivalent to the direct response. Thus, the gain value obtained in indirect selection by plant height, in relation to direct gains with dry matter yield, especially in the fourth cut, is indicative of the potential of this trait for indirect or simultaneous selection in alfalfa breeding. In general, the direct gains in all traits were consistent with the pre-determined objective (an increase in

Table 4. Estimates of genotypic (upper diagonal) and phenotypic correlation (lower diagonal) for dry matter yield (DMY), plant height $(\mathrm{PH})$ and susceptibility to diseases (SD).

\begin{tabular}{lccc}
\hline \multicolumn{1}{c}{ CUT 1 } & PH & DMY & SD \\
\hline PH & - & 0.0605 & 0.0000 \\
DMY & 0.1384 & - & 0.0000 \\
SD & -0.2050 & -0.0971 & - \\
\hline \multicolumn{1}{c}{ CUT 2 } & PH & DMY & SD \\
\hline PH & - & 0.6664 & 0.6275 \\
DMY & 0.6489 & - & 0.5069 \\
SD & 0.6654 & 0.4352 & - \\
\hline \multicolumn{1}{c}{ CUT 3 } & PH & DMY & SD \\
\hline PH & - & 0.7901 & 0.1048 \\
DMY & 0.6869 & - & -0.1757 \\
SD & 0.1350 & -0.0715 & - \\
\hline \multicolumn{1}{c}{ CUT 4 } & PH & DMY & SD \\
\hline PH & - & 0.7055 & 1.0000 \\
DMY & 0.8504 & - & 0.9421 \\
SD & 0.2228 & 0.1433 & - \\
\hline
\end{tabular}


Table 5. Estimates of genotypic (upper diagonal) and phenotypic (lower diagonal) correlation for stem/leaf ratio (SLR), lignin (L), crude protein (CP), in vitro dry matter digestibility (IVDMD), neutral detergent fiber (NDF) and acid detergent fiber (ADF) in alfalfa.

\begin{tabular}{|c|c|c|c|c|c|c|}
\hline CUT 1 & SLR & $\mathrm{L}$ & $\mathrm{CP}$ & IVDMD & NDF & ADF \\
\hline SLR & - & 0.5487 & -0.5828 & -1.1310 & 0.5668 & 0.9953 \\
\hline $\mathrm{L}$ & 0.2293 & - & 0.0457 & -0.8499 & 0.3647 & 0.4581 \\
\hline $\mathrm{CP}$ & -0.4333 & -0.0235 & - & 0.7640 & -0.0292 & -0.1513 \\
\hline IVDMD & -0.4770 & -0.4390 & 0.4306 & - & -1.1122 & -1.1677 \\
\hline NDF & 0.3247 & 0.3626 & -0.1052 & -0.3445 & - & 0.5593 \\
\hline $\mathrm{ADF}$ & 0.5461 & 0.5222 & -0.3269 & -0.6197 & 0.5268 & - \\
\hline CUT 2 & SLR & $\mathrm{L}$ & $\mathrm{CP}$ & IVDMD & NDF & $\mathrm{ADF}$ \\
\hline SLR & - & 0.0000 & -0.6200 & -1.1894 & 0.0000 & 0.4641 \\
\hline $\mathrm{L}$ & 0.0315 & - & 0.0000 & 0.0000 & 0.0000 & 0.0000 \\
\hline $\mathrm{CP}$ & -0.6215 & -0.0302 & - & 1.0000 & 0.0000 & -0.8723 \\
\hline IVDMD & -0.4288 & -0.0131 & 0.7796 & - & 0.0000 & -0.8506 \\
\hline NDF & 0.3346 & 0.6647 & -0.4616 & -0.3441 & - & 0.0000 \\
\hline $\mathrm{ADF}$ & 0.3287 & -0.0962 & -0.6081 & -0.4498 & 0.2265 & - \\
\hline CUT 3 & SLR & $\mathrm{L}$ & $\mathrm{CP}$ & IVDMD & NDF & $\mathrm{ADF}$ \\
\hline SLR & - & -0.2677 & -0.7485 & -0.9180 & 0.5419 & 0.5640 \\
\hline $\mathrm{L}$ & -0.0223 & - & 0.3455 & 0.5603 & 0.0181 & -0.3651 \\
\hline $\mathrm{CP}$ & -0.8554 & 0.0726 & - & 1.0484 & -0.5154 & -0.6195 \\
\hline IVDMD & -0.6528 & 0.0851 & 0.8151 & - & -0.8920 & -1.0255 \\
\hline NDF & 0.4976 & 0.5338 & -0.5793 & -0.5057 & - & 0.4192 \\
\hline $\mathrm{ADF}$ & 0.6050 & 0.0730 & -0.6167 & -0.5155 & 0.4393 & - \\
\hline CUT 4 & SLR & $\mathrm{L}$ & $\mathrm{CP}$ & IVDMD & NDF & $\mathrm{ADF}$ \\
\hline SLR & - & -0.2544 & -0.6982 & -0.8006 & 0.4548 & 0.0000 \\
\hline $\mathrm{L}$ & -0.1737 & - & 0.2308 & 0.5700 & 0.0087 & 0.0000 \\
\hline $\mathrm{CP}$ & -0.6933 & 0.1695 & - & 0.8200 & -0.7306 & 0.0000 \\
\hline IVDMD & -0.6450 & 0.1393 & 0.6292 & - & -0.1593 & 0.0000 \\
\hline NDF & 0.2846 & 0.5613 & -0.3897 & -0.3239 & - & 0.0000 \\
\hline $\mathrm{ADF}$ & 0.5038 & -0.0125 & -0.4453 & -0.2702 & 0.0976 & - \\
\hline
\end{tabular}

Table 6. Predicted responses with direct and indirect selections in alfalfa cultivars for dry matter yield (DMY), plant height $(\mathrm{PH})$ and susceptibility to diseases (SD).

\begin{tabular}{ccccc}
\hline \multirow{2}{*}{ Cut } & \multirow{2}{*}{ Selection } & \multicolumn{3}{c}{ Predicted response (\%) } \\
\cline { 3 - 5 } & & \multicolumn{1}{c}{ PH } & DMY & SD \\
\hline \multirow{3}{*}{1} & PH & 3.94 & -0.76 & 0.00 \\
& DMY & 9.24 & 0.41 & 0.00 \\
& SD & -0.46 & -1.25 & 0.00 \\
\hline \multirow{3}{*}{2} & PH & 6.60 & 4.77 & 5.01 \\
& DMY & 4.00 & 11.56 & 3.81 \\
& SD & 3.32 & 2.70 & 5.81 \\
\hline \multirow{3}{*}{3} & PH & 8.66 & 6.42 & 1.61 \\
& DMY & 6.25 & 10.35 & 0.03 \\
& SD & 1.37 & -0.55 & 8.23 \\
\hline \multirow{3}{*}{4} & PH & 23.60 & 20.60 & 0.03 \\
& DMY & 17.61 & 27.11 & 0.01 \\
& SD & 4.54 & 1.87 & 0.06 \\
\hline
\end{tabular}

plant height, dry matter yield and susceptibility to diseases).

The selection for lignin reduction at the first cut led to a negative result for crude protein
(Table 7). Positive gains for crude protein are important, because values below recommendation may limit milk yield (Oliveira 2014). For the second cut, even though lignin and neutral detergent fiber presented values of genetic variance equal to zero, and in vitro dry matter digestibility presented nonsignificant genetic variance, they were maintained in the analysis, as they would not influence the gains of the remaining traits (Table 7). Overall, the gain estimates for this cut were low. For the third cut, lignin and in vitro dry matter digestibility had no significant genetic variance, not providing gains to the cultivars. Responses to direct selection were quite interesting for breeding purposes, especially for crude protein, which showed a direct gain of $7.07 \%$. The indirect gain obtained with the direct selection in crude protein represented $-1.01 \%$ and $-1.40 \%$, respectively for neutral detergent fiber and acid detergent fiber (Table 7).

At the fourth cut, the genetic variance for acid detergent fiber was zero, and for neutral detergent 
fiber was non-significant. Even so, these traits were maintained in the analysis. In this case, estimates of direct and indirect gains were inconsistent with the desired ones, except for direct selection in neutral detergent fiber, which provided an increase in crude protein and in vitro dry matter digestibility, as well as a decrease in the remaining traits (Table 7). Since most alfalfa traits are heavily influenced by the environment, even interesting direct selection results should be carefully evaluated to avoid misinterpretation.

According to Botrel et al. (2001), it is fundamental to maintain the highest proportion of leaves in the forage harvested, as this results in forage with a high nutritive value. This is important mainly during the dry season, when the nutritive value of the forage falls sharply. Using univariate selections, it was possible to reduce the stem/leaf ratio in most of the cuts (Table 7).

The results for direct and indirect selection were similar to those found by Vasconcelos et al. (2010), who investigated the genetic gain by different selection criteria in alfalfa. These authors found higher gains for some traits with direct selection, but obtained indirect undesired gains, leading to an increase in susceptibility to disease. They pointed out that none of the direct alfalfa selections provided satisfactory gains for all the evaluated traits. Obtaining favorable responses to a set of traits has not been an easy task in other perennial species, such as eucalyptus (Eucalyptus grandis) and passion fruit (Passiflora edulis).

In some studies, for instance, Martins et al. (2003), who investigated the efficiency of direct and indirect selection and index selection in eucalyptus, there is no efficiency for both methods. The authors concluded that the simultaneous selection processes were efficient to provide more balanced gains in the genotypes. Another example is the study of Freitas et al. (2012), who investigated the formation of a base population for recurrent selection in yellow passion fruit. They concluded that selection with a focus on productivity presented undesirable gains for a set of traits.

The selection gains obtained using the Tai index for forage yield traits, in all cuts, allowed

Table 7. Predicted responses with direct and indirect selections in alfalfa cultivars for lignin (L), crude protein (CP), in vitro dry matter digestibility (IVDMD), neutral detergent fiber (NDF), acid detergent fiber (ADF) and stem/leaf ratio (SLR).

\begin{tabular}{|c|c|c|c|c|c|c|c|}
\hline \multirow{2}{*}{ Cut } & \multirow{2}{*}{ Selection } & \multicolumn{6}{|c|}{ Predicted response (\%) } \\
\hline & & $\mathrm{L}$ & $\mathrm{CP}$ & IVDMD & NDF & $\mathrm{ADF}$ & SLR \\
\hline \multirow{6}{*}{1} & $\mathrm{~L}$ & -8.22 & -0.52 & 0.25 & -2.30 & -1.78 & -0.75 \\
\hline & $\mathrm{CP}$ & -1.31 & 2.65 & 0.37 & -0.26 & -1.68 & -1.31 \\
\hline & IVDMD & -4.60 & 1.66 & 0.70 & -1.44 & -2.14 & -1.74 \\
\hline & NDF & -3.40 & 0.71 & 0.25 & -4.40 & -2.68 & -0.89 \\
\hline & $\mathrm{ADF}$ & -3.18 & 1.21 & 0.32 & -3.05 & -3.45 & -1.90 \\
\hline & SLR & -2.90 & 1.00 & 0.44 & -1.76 & -2.43 & -2.89 \\
\hline \multirow{6}{*}{2} & $\mathrm{~L}$ & 0.00 & -0.01 & 0.00 & 0.00 & 0.24 & -1.46 \\
\hline & $\mathrm{CP}$ & 0.00 & 2.86 & 0.13 & 0.00 & -0.57 & -6.38 \\
\hline & IVDMD & 0.00 & 2.25 & 0.17 & 0.00 & -0.48 & -3.54 \\
\hline & NDF & 0.00 & 0.88 & 0.03 & 0.00 & -0.04 & -3.50 \\
\hline & $\mathrm{ADF}$ & 0.00 & 1.86 & 0.07 & 0.00 & -1.17 & -3.46 \\
\hline & SLR & 0.00 & 2.10 & 0.05 & 0.00 & -0.62 & -9.50 \\
\hline \multirow{6}{*}{3} & $\mathrm{~L}$ & -0.66 & -0.49 & -0.02 & -0.80 & -0.13 & 0.01 \\
\hline & $\mathrm{CP}$ & -0.06 & 7.07 & 0.38 & -1.01 & -1.40 & -9.95 \\
\hline & IVDMD & 0.00 & 5.82 & 0.44 & -0.72 & -1.07 & -8.68 \\
\hline & NDF & -0.38 & 4.17 & 0.22 & -1.51 & -1.15 & -5.96 \\
\hline & $\mathrm{ADF}$ & -0.06 & 3.87 & 0.25 & -0.68 & -2.09 & -6.65 \\
\hline & SLR & -0.12 & 6.36 & 0.34 & -0.97 & -1.48 & -10.62 \\
\hline \multirow{6}{*}{4} & $\mathrm{~L}$ & -2.22 & -0.26 & 0.02 & -0.71 & 0.00 & -0.41 \\
\hline & $\mathrm{CP}$ & 0.79 & 4.27 & 0.43 & -0.41 & 0.00 & -11.97 \\
\hline & IVDMD & 0.44 & 2.34 & 0.57 & -0.37 & 0.00 & -9.94 \\
\hline & NDF & -1.25 & 1.92 & 0.24 & -1.44 & 0.00 & -6.04 \\
\hline & $\mathrm{ADF}$ & 0.44 & 1.72 & 0.14 & 0.02 & 0.00 & -6.19 \\
\hline & SLR & 0.92 & 2.91 & 0.41 & -0.41 & 0.00 & -14.28 \\
\hline
\end{tabular}


positive gains for plant height and dry matter yield (Table 8). Cruz et al. (2014) state that simultaneous selection is a practice that maximizes the success in the breeding process. In fact, simultaneous selection was more efficient than direct and indirect selections, because they provided, in the majority of the cuts, more balanced gains. In the literature, it has been reported that indices offer the possibility of obtaining selective gains, even for unfavorably correlated traits (Granate et al. 2002).

Considering the nutritive value traits, the gains were also more balanced, when compared to those of the direct and indirect selections (Table 8). For the first and second cuts, the gain estimates reached acceptable values for all traits. However, the gain for the in vitro dry matter digestibility in the first cut; lignin, in vitro dry matter digestibility and neutral detergent fiber in the second cut; lignin and in vitro dry matter digestibility in the third cut; and neutral detergent fiber and acid detergent fiber in the fourth cut should not be interpreted as real gains, since these had non-significant genetic variances (Table 8). In the fourth cut, there was a positive gain for lignin $(0.01 \%)$. However, as the gain for the other components were satisfactory, and since the genotype set showed optimal results for nutritive value, this specific gain value should not result in major problems.

The results for direct, indirect and simultaneous selection show the inconsistency of the univariate selections. The result obtained for direct selection in plant height, in the first cut (Table 6), for example, led to a reduction in the dry matter yield. In the other cuts, the result of this direct selection led to an increase in dry matter yield. However, when all the traits of forage yield were evaluated in the index, there was a positive gain for plant height and dry matter yield simultaneously, in all cuts. This result shows that, even in diverse environmental conditions, the index is able to select genotypes that will return gains compatible with the ones expected by the researcher, a fact that is not observed in the univariate selections.

Although this study considered two separate groups of variables, it is of interest to conduct a joint interpretation to identify cultivars that demonstrate superiority among all the measured traits with economic and, or, phytotechnical importance. Using the selection index approach, a "super phenotypic trait" was obtained, which combines all the important traits. The Tai (1977) selection index is a linear combination of the traits, which maintains maximum correlation with the genotypic aggregate. Each individual will have a score for the index. Considering the selection of $25 \%$ of the cultivars in each of the four cuts and in each trait group, the simultaneous selection by the Tai index was more efficient than the univariate selections, because it allowed balanced gains for each set of traits (Table 8). However, when the results obtained in all cuts were individually compared between the two groups - forage yield and nutritive value - the selection for both groups was difficult (Figure 1). Only in the first and second cuts (Figures $1 \mathrm{a}$ and $1 \mathrm{~b}$ ) it was possible to identify accessions that could be selected for both groups. Accessions 1 and 67, in the first cut, were selected simultaneously for both forage yield and nutritive value (5681 and Verdor cultivars, respectively). In the second cut, the accession 56 (ProINTA Patricia) was selected. The selection for forage yield and nutritive value groups was not possible in the third and fourth cuts, because of the negative correlations between these two groups of traits in these cuts (Figure 1). However, it was noted, in all cuts, that there were cultivars very close to the selection value established in the two groups.

The adoption of simultaneous selection is supported by two basic reports. The first one refers to

Table 8. Simultaneous selection using the Tai index in the four alfalfa cuts for the traits of forage yield and nutritive value.

\begin{tabular}{|c|c|c|c|c|c|c|c|c|c|}
\hline \multirow{3}{*}{ Cuts } & \multicolumn{9}{|c|}{ Selection gain $(\%)$} \\
\hline & \multicolumn{3}{|c|}{ Forage yield } & \multicolumn{6}{|c|}{ Nutritive value } \\
\hline & $\mathrm{PH}^{*}$ & DMY & SD & $\mathrm{L}$ & $\mathrm{CP}$ & IVDMD & NDF & $\mathrm{ADF}$ & SLR \\
\hline 1 & 0.35 & 8.77 & 0.00 & -2.78 & 2.36 & 0.55 & -1.24 & -1.68 & -1.95 \\
\hline 2 & 5.92 & 9.77 & 4.61 & 0.00 & 2.21 & 0.12 & 0.00 & -0.97 & -6.53 \\
\hline 3 & 8.27 & 6.53 & -0.91 & 0.05 & 6.54 & 0.42 & -0.74 & -1.19 & 3.79 \\
\hline 4 & 20.99 & 26.32 & 0.03 & 0.01 & 6.51 & 0.42 & -0.83 & -1.34 & -10.17 \\
\hline
\end{tabular}

* PH: plant height; DMY: dry matter yield; SLR: stem/leaf ratio; SD: susceptibility to diseases; L: lignin; CP: crude protein; IVDMD: in vitro dry matter digestibility; NDF: neutral detergent fiber; ADF: acid detergent fiber. 
a

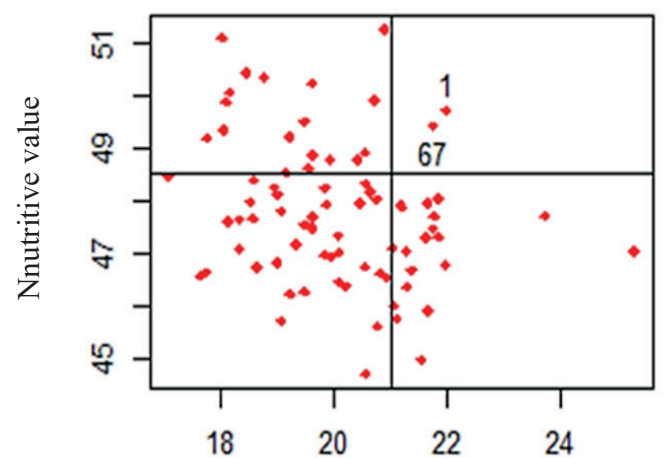

c

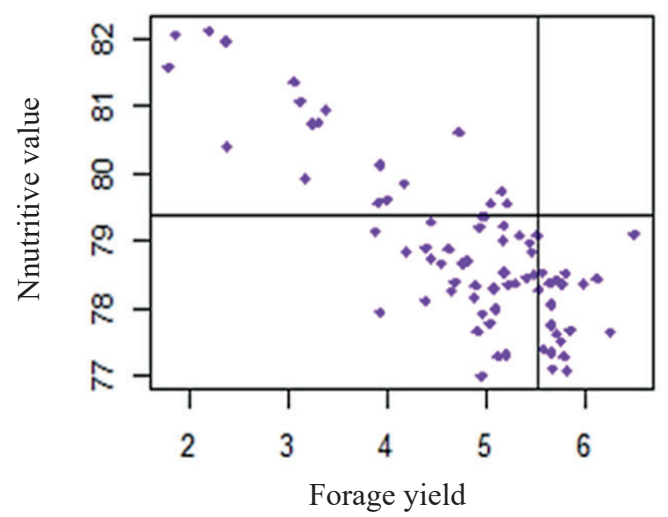

b

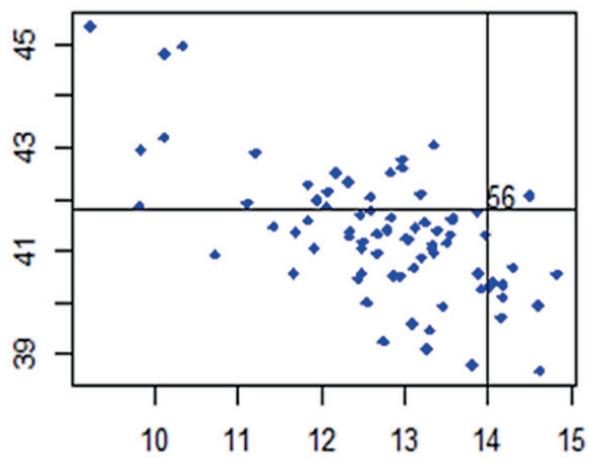

d

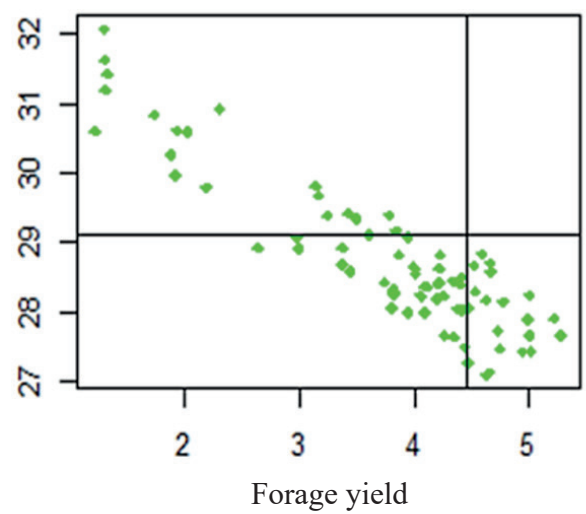

Figure 1. Cultivars selection by the Tai (1977) index for the forage yield and nutritive value groups, for the first (a), second (b), third (c) and fourth (d) cuts.

the fact that, among all strategies, the index selection has been more efficient (Hazel \& Lush 1942, Cruz et al. 2014). The second one, in the agronomic context, is based on the findings by Li \& Brummer (2012) that alfalfa breeding should include, besides an increase in forage yield, improvement in the forage nutritive value. However, in general, it was found that there are difficulties in bringing together cultivars that provide balanced gains within each trait group and that are favorable in another group. Certainly, the simultaneous selection does not exclude the possibility of aggregating the tandem selection strategy to select complexes, rather than individual traits. In the present study, it should also be considered that, according to the parameters proposed by Rassini et al. (2007), the set of genotypes studied already presents a high nutritive value and, therefore, the selection for this group could be more flexible. In this case, a greater number of genotypes could be selected according to the objectives set, in terms of high forage yield and high nutritive value.

\section{CONCLUSIONS}

1. Direct and indirect selections among genotype averages are not efficient to provide desirable responses to the whole set of traits for alfalfa;

2. The Tai index provides a more balanced distribution of gains for the traits of forage yield and nutritive value for alfalfa in all cuts, in relation to the univariate selections;

3. The simultaneous selection for the forage yield and nutritive value groups allowed the identification of the 5681 and Verdor cultivars in the first cut, and ProINTA Patricia in the second cut, as superior in the two groups of traits.

\section{REFERENCES}

ANNICCHIARICO, P. et al. Achievements and challenges in improving temperate perennial forage legumes. Critical Reviews in Plant Sciences, v. 34, n. 1, p. 327-380, 2015. 
BASIGALUP, D. H.; ODORIZZI, A. S. Melhoramento genético da alfafa. In: FERREIRA, R. P.; BASIGALUP, D. H.; GIECO, J. O. (Eds.). Melhoramento genético da alfafa. São Carlos: Embrapa Pecuária Sudeste, 2011. p. 225-260.

BOTREL, M. A. et al. Cultivares de alfafa em área de influência da Mata Atlântica no estado de Minas Gerais. Pesquisa Agropecuária Brasileira, v. 36, n. 11, p. 14371442, 2001.

BOUTON, J. The economic benefits of forage improvement in the United States. Euphytica, v. 154, n. 3, p. 263-270, 2007.

COMERON, E. A. et al. Utilização da alfafa em pastejos para alimentação de vacas leiteiras. In: FERREIRA, R. P. et al. (Eds.). Cultivo e utilização da alfafa em pastejo para alimentação de vacas leiteiras. Brasília, DF: Embrapa, 2015. p. 131-150.

COSTA, M. M.; MEIRELlES, P. R.; VIEIRA, M. E. Q. Produção de matéria seca e composição bromatológica de vinte cultivares de alfafa (Medicago sativa L.) em Botucatu SP. Veterinária e Zootecnia, v. 12, n. 1, p. 42-51, 2006.

CRUZ, C. D. Genes: a software package for analysis in experimental statistics and quantitative genetics. Acta Scientiarum Agronomy, v. 35, n. 3, p. 271-276, 2013.

CRUZ, C. D.; CARNEIRO, P. C. S.; REGAZZI, A. J. Modelos biométricos aplicados ao melhoramento genético. Viçosa: Ed. da UFV, 2014.

FALCONER, D. S. Introdução à genética quantitativa. Viçosa: Ed. da UFV, 1981.

FERREIRA, R. P. et al. Genética quantitativa e métodos de melhoramento em alfafa. In: FERREIRA, R. P. et al. (Eds.). Cultivo e utilização da alfafa nos trópicos. São Carlos: Embrapa Pecuária Sudeste, 2008. p. 171-205.

FERREIRA, R. P.; VILELA, D. Potencial de utilização da alfafa. In: FERREIRA, R. P. et al. (Eds.). Cultivo e utilização da alfafa em pastejo para alimentação de vacas leiteiras. Brasília, DF: Embrapa, 2015. p. 13-16.

FREITAS, J. P. X. et al. Formação de população base para a seleção recorrente em maracujazeiro-amarelo com uso de índices de seleção. Pesquisa Agropecuária Brasileira, v. 47, n. 3, p. 393-401, 2012.

GRANATE, M. J.; CRUZ, C. D.; PACHECO, C. A. P. Predição de ganho genético com diferentes índices de seleção no milho pipoca CMS-43. Pesquisa Agropecuária Brasileira, v. 37, n. 7, p. 1001-1008, 2002.

GUINES, F. et al. Genetic control of quality traits of lucerne (Medicago sativa L.). Australian Journal of Agricultural Research, v. 53, n. 4, p. 401-407, 2002.

HALLAUER, A. R. et al. Means and variances. In: HALlAUER, A. R.; CARENA, M. J.; MIRANDA
FILHO, J. B. (Eds.). Quantitative genetics in maize breeding. New York: Springer-Verlag, 2010. p. 33-67.

HAZEL, L. N.; LUSH, J. L. The efficiency of three methods of selection. Journal Heredity, v. 33, n. 11, p. 393-399, 1942.

JULIER, B.; HUYGHE, C.; ECALE, C. Within and among cultivar genetic variation in alfafa: forage quality, morphology, and yield. Crop Science, v. 40, n. 2, p. 365369, 2000.

KATEPA-MUPONDWA, F. M.; CHRISTIE, B. R.; MICHAELS, T. E. An improved breeding strategy for autotetraploidy alfafa (Medicago sativa L.). Euphytica, v. 123, n. 1, p. 139-146, 2002.

LI, X. et al. Genomic prediction of biomass yield in two selection cycles of a tetraploid alfalfa breeding population. The Plant Genome, v. 8, n. 2, p. 1-10, 2015.

LI, X.; BRUMMER, E. C. Applied genetics and genomics in alfalfa breeding. Agronomy, v. 2, n. 1, p. 40-61, 2012.

MARTINS, I. S. et al. Eficiência da seleção univariada direta e indireta e de índices de seleção em Eucalyptus grandis. Revista Árvore, v. 27, n. 3, p. 327-333, 2003.

MILIC, D. et al. Breeding and improvement of quality traits in alfalfa (Medicago sativa ssp. sativa L.). Genética, v. 46, n. 1, p. 11-18, 2014.

OLIVEIRA, A. Gado de leite: a importância das forrageiras no sistema de produção a pasto. 2014. Available at: <https://www.cpt.com.br/cursos-bovinos-gadodeleite/ artigos/gado-de-leite-a-importancia-das-forrageiras-nosistema-de-producao-a-pasto>. Access on: 28 May 2017.

RADOVIC, J. S. D.; MARKOVIC, J. Alfalfa: most important perennial forage legume in animal husbandry. Biotechnology in Animal Husbandry, v. 25, n. 5, p. 465475, 2009.

RASSINI, J. B. et al. Qualidade da forragem de alfafa na região Sudeste do Brasil. 2007. Available at: $<$ https://ainfo. cnptia.embrapa.br/digital/bitstream/CPPSE/17079/1/ PROCIJBR2007.00088.pdf>. Access on: 20 Nov. 2017.

RASSINI, J. B. Manejo da água na irrigação da alfafa num Latossolo Vermelho-Amarelo. Pesquisa Agropecuária Brasileira, v. 37, n. 4, p. 503-507, 2002.

ROBINS, J. G.; BAUCHAN, G. R.; BRUMMER, E. C. Genetic mapping forage yield, plant height, and regrowth at multiple harvests in tetraploid alfalfa (Medicago sativa L.). Crop Science, v. 47, n. 1, p. 11-18, 2007.

SILVA, M. G. M. et al. Biometria aplicada ao melhoramento intrapopulacional do maracujazeiro amarelo. Revista Ciência Agronômica, v. 43, n. 3, p. 493-499, 2012. 
SOUZA SOBRINHO, F. et al. Estimativas de repetibilidade para produção de matéria seca em alfafa. Ciência Rural, v. 34, n. 1, p. 531-537, 2004.

TAI, G. C. C. Index selection with desired gains. Crop Science, v. 17, n. 1, p. 182-183, 1977.

TUCAK, M. et al. Agro-morphological and forage quality traits of selected alfalfa populations and their application in breeding. Turkish Journal of Field Crops, v. 19, n. 1, p. 79-83, 2014.

UNITED NATIONS. World population prospects: the 2017 revision, key findings and advance tables. 2017. Available at: <https://esa.un.org/unpd/wpp/publications/Files/ WPP2017_KeyFindings.pdf $>$. Access on: 20 Jun. 2018.
VASCONCELOS, E. S. et al. Estimativas de ganho genético por diferentes critérios de seleção em genótipos de alfafa. Revista Ceres, v. 57, n. 2, p. 205-210, 2010.

VIANA, M. C. M. et al. Avaliação de cultivares de alfafa nas condições de Cerrado no estado de Minas Gerais. Pesquisa Agropecuária Brasileira, v. 39, n. 3, p. 289292, 2004.

ZHANG, T. et al. Identification of loci associated with drought resistance traits in heterozygous autotetraploid alfalfa (Medicago Sativa L.) using genome-wide association studies with genotyping by sequencing. PLoS One, v. 10, n. 9, p. e0138931, 2015. 